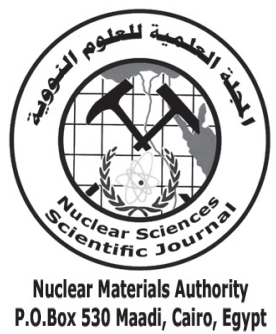

ISSN 2314-5609

Nuclear Sciences Scientific Journal

vol. 2, p 23 - 37

2013

\title{
ALKALIC-METASOMATISM AND REDISTRIBUTION OF U, THAND REE IN THE HYDROTHERMALLY ALTERED GRANITE OF GABAL ABU HARBA, NORTH EASTERN DESERT, EGYPT
}

ABDEL AZEEM A. RASHWAN, MAHMOUD H. SHALABY ${ }^{1}$, MOHAMED E. ROZ ${ }^{\text {, }}$ MOHAMED A. WETAIT , AMR A. ABDEL HAMID ${ }^{1}$

Depart. Geol., Fac. Sci., Benha Univ., P.O. 13518 Benha, Egypt; ${ }^{1}$ Nuclear Materials Authority, P.O. 530 El-Maadi, Kattamyia, Egypt

\begin{abstract}
The late Pan-African granites of Gabal Abu Harba area occur in the North Eastern Desert of Egypt. Field and mineralogical studies indicate that the granites comprise coarse-grained biotite granite and mediumgrained leucogranite. The geochemical characteristics categorize these rocks as syenogranite and alkali feldspar granite according to the Ab-Or-An normative values. The syenogranite, as compared with the alkali feldspar granite, possesses lower $\mathrm{A} / \mathrm{CNK}$ ratio values, higher $\mathrm{P}_{2} \mathrm{O}_{5}, \mathrm{CaO}, \mathrm{TiO}_{2}, \mathrm{Sr}$ and $\mathrm{Ba}$ contents, and is depleted in $\mathrm{Rb}, \mathrm{Nb}, \mathrm{Th}, \mathrm{U}$. The $\mathrm{U}$ contents of the alkali feldspar granite (average $=12.3 \mathrm{ppm}$ ) suggest fertile-U source to constitute a suitable setting for uranium minerals formation by later hydrothermal fluids. The alkali feldspar granite was affected by hydrothermal solutions along its fault planes, causing a series of zones of wall-rock chloritization, sericitization, kaolinitization, carbonatization and hematitization as well as highly enrichment of $U$ and slight mobilization for Th. The secondary uranium minerals, locally identified in these altered parts, comprise chiefly beta-uranophane and kasolite. Whole-rock geochemistry shows that the altered alkali feldspar granite experienced both sodic and potassic metasomatism. Mass balance calculations, with reference to unaffected alkali feldspar granite, evidenced loss for $\mathrm{SiO}_{2}, \mathrm{TiO}_{2}$, $\mathrm{FeO}, \mathrm{MgO}, \mathrm{CaO}$ and $\mathrm{K}_{2} \mathrm{O}$ and LREE contents, and gain of both the HREE (Tm, $\mathrm{Yb}$ and $\mathrm{Lu}$ ) and most of the trace elements ( $\mathrm{Sr}, \mathrm{U}, \mathrm{Zn}$ and $\mathrm{Pb})$.
\end{abstract}

\section{INTRODUCTION}

Among felsic igneous rocks, three types may constitute a uranium sources for the genesis of uranium deposits with uranium contents well above the Clarke value (3-4 ppm): 1) highly fractionated peralkaline rocks, 2) metaluminous high- $\mathrm{K}$ alkaline to calcalkaline rocks and 3) peraluminous igneous rocks derived from low degree of melting of supracrustals (Cuney, 2009). They have been regarded as the source of uranium all over the world (France: Scaillet et al., 1996; Namibia: Nex et al., 2001; Germany: Dill et al.,2010; China; Zhao et al., 2011; Ukrain: Cuney et al.,
2012). Uranium ores associating the granitic rocks in Egypt are mainly of the hydrothermal vein-type, mainly controlled by tectonic faults (Cuney, 2003). They are occasionally associated with wide range of wall-rock alteration features. Alkali metasomatism represents one of these alteration signatures playing an important role in guiding uranium exploration (Dahlkamp, 1993).

Gabal Abu Harba granites contains an important occurrences of uranium mineralization. Previous studies have focused on the geolog and radioactivity of these uranium occurrences (Roz, 2001). This contribution pres- 
ents the mineralogical and chemical changes associated with the uranium mineralization in the altered parts of G. Abu Harba granites. The study also discusses the redistribution patterns of each $\mathrm{U}$, Th and REE during these processes.

\section{SAMPLING AND ANALYTICAL METHODS}

A total of 94 specimens were collected from surface exposures of the least altered granites and along the altered mineralized joints of the alkali feldspar granite. The mineralized samples show variable degrees of alterations represented by kaolinitization, hematitization and dendritic Mn-oxides. Forty two thin sections were prepared for petrographical investigation.

Whole-rock major-, trace- and rare earth elements analyses were carried out on 27 samples at the ALS-Lab, Spain. The major elements were analyzed by plasma-atomic emission spectrometry (ICP-AES) while the trace and rare earth elements were analyzed using fusion inductively coupled plasma spectrometry (ICP).

Scratched secondary uranium minerals from the sample surfaces were separated individually by careful hand picking using a binocular microscope. They were identified by using X-ray Generator model Philips PW3710 with generator PW-1830, Cu target tube and Ni filter at $40 \mathrm{kV}$ and $30 \mathrm{~mA}$ in the Nuclear Materials Authority Lab. Secondary uranium minerals were analyzed using an Environmental Scanning Electron Microscope (ESEM) supported by energy dispersive spectrometer (EDS) unit at the central laboratories of the Geological Survey of Egypt.

\section{GEOLOGIC SETTING}

The studied area occupies ab. $200 \mathrm{~km}^{2}$ in North Eastern Desert, Egypt ( lat. 270 13' 36" to $27^{\circ} 22^{\prime} 00^{\prime \prime} \mathrm{N}$ and long. $33^{\circ} 06^{\prime} 00^{\prime \prime}$ to $33^{\circ}$ 14' 21" E), (Fig.1). The exposed rock suites in G. Abu Harba area are related to the Pan-African orogeny of the Neoproterozoic ArabianNubian Shield. The area is essentially covered by late Pan-African granites intruded into volcanic rocks, consisting of island arc metavolcanics and Dokhan volcanics.

The late Pan African granites of the Arabian-Nubian shield, including G. Abu Harba granites, are formed in the last stage of the shield evolution, when a fundamental transition in tectonic style, from compressional to extensional, occurred 620-600My ago (Stern

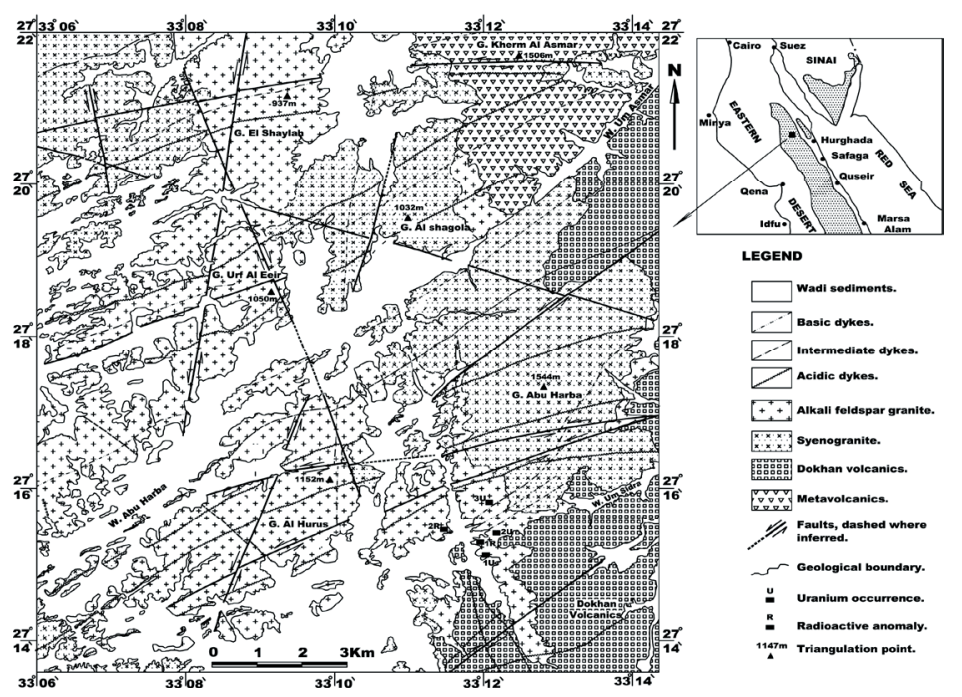

Fig. 1: Geologic map of Gabal Abu Harba area 
et al., 1984; Bentor, 1985; Kröner et al., 1987; Stern, 1994; Genna et al., 2002; Meert, 2003). The age determined for $\mathrm{G}$. Abu Harba granites are ranging between 595 and $605 \mathrm{Ma}$ (Moussa et al., 2008).

The metavolcanics are the oldest rock unit and exposed at G. Kherm Al Asmar. They are intruded by the granites and range in composition from metabasalts to meta-andesites commonly exhibiting porphyritic texture. The mapped parts of the Dokhan volcanics consist of vary-colored alternating successions of lava flows of andesites, dacites and rhyolites interlayered with pyroclastic rocks of tuffs and agglomerates. The contacts between the volcanics and the granites are sharp, non-reactive and dip gently or steeply away from the granite body (Fig.2).

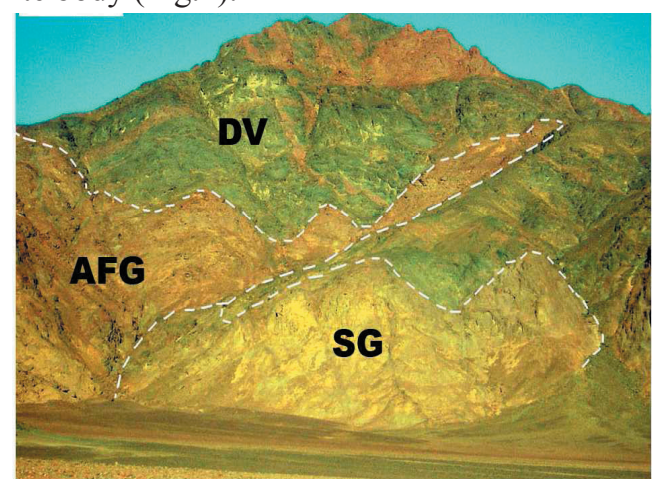

Fig.2: Sharp contacts between the studied granites and the Dokhan volcanics SG: Syenogranite, AFG: Alkali feldspar granite, DV: Dokhan volcanics

Detailed field investigation coupled with petrographical and geochemical studies revealed that $\mathrm{G}$. Abu Harba granites comprise two types of syenogranite and alkali feldspar granite. The contact between the two granitic types is almost gradational, which implies a comagmatic relation. The syenogranite is generally characterized by low to moderate outcrops but it forms high ridges within G. Abu Harba itself. It is medium-grained and porphyritic and usually contains some xenoliths of mafic materials. On the other hand, the alkali feldspar granite is commonly forming highly elevated rough ridges (Fig.3) and is almost free of xenoliths. It is medium-grained and display hybidiomorphic equigranular texture.

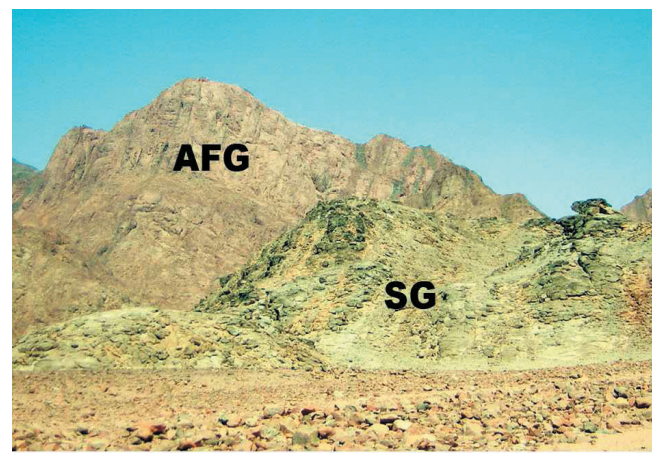

Fig.3: The alkali feldspar granite forming high mountains compared to the syenogranite. SG: Syenogranite, AFG: Alkali feldspar granite

The study area is intersected by sets of faults prevailing, with decreasing order in abundances, in the NE-SW, ENE-WSW and $\mathrm{N}-\mathrm{S}$ directions (Fig. 1). Dyke swarms of different compositions trending NE-SW are common. The granites are cut by numerous pegmatite veins, aplites and quartz veins.

The hydrothermal alterations are found within the fracture network of the alkali feldspar granite that created by the action of natural fluids on the rocks. The hydrothermal alterations are pervasive and locally associated with uranium deposition. The alterations comprise hematitization (Fig.4), kaolinitization, silicification, chloritization as well as epidotization and frequent presence of dentritic manganese oxides. Three uranium occurrences $1 \mathrm{U}, 2 \mathrm{U}$ and $3 \mathrm{U}$ are located in the alkali feldspar granite of G. Abu Harba along its western marginal parts at the extreme southeastern parts of the mapped area (Fig.1). The secondary uranium minerals occur as staining or filling the microfractures of the altered alkali feldspar granite (Fig.5). Most of the uranium mineralizations in the study area are strictly structural-hosted. The NE-SW, NNW-SSE and N-S trending fractures are the main mineralized ones. 


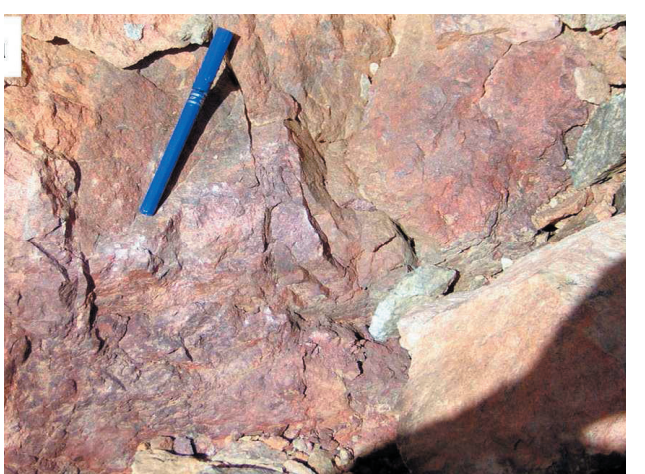

Fig.4: Field photograph of the altered alkali feldspar granite showing different shades of hematitization

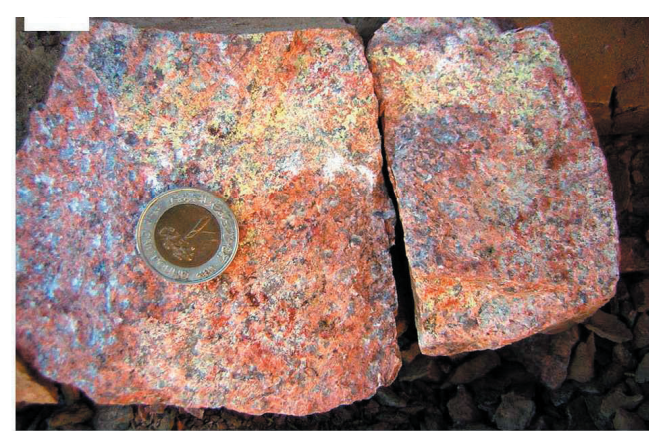

Fig.5: Field photograph of the altered alkali feldspar granite showing secondary uranium minerals staining joint planes

\section{PETROGRAPHY OF THE GRANITES}

The syenogranite consists of k-feldspar, quartz, plagioclase and biotite. The accessory minerals include titanite, zircon, apatite, fluorite and iron oxides (Fig.6). Muscovite, epidote and chlorite are the secondary minerals. $\mathrm{K}$-feldspar is anhedral but quartz is subhedral to anhedral grains. Perthitic texture is common and patch type is dominant. Plagioclases form prismatic crystals and frequently zoned. Brown biotite is the common mafic mineral and occurs as subhedral flakes. Titanite, zircon and apatite are much abundant in this granite type.

The alkali feldspar granite is composed of $\mathrm{k}$-feldspar, quartz and plagioclase as essential minerals (Fig.7). Biotite, muscovite, zircon, monazite, fluorite and iron oxides are accessories. The chlorite, sericite, epidote and cal- cite are the secondary minerals. The amount of accessory fluorite in this granite is noticeably higher. Zircon is characterized by zonation and inclusions of radioactive minerals.

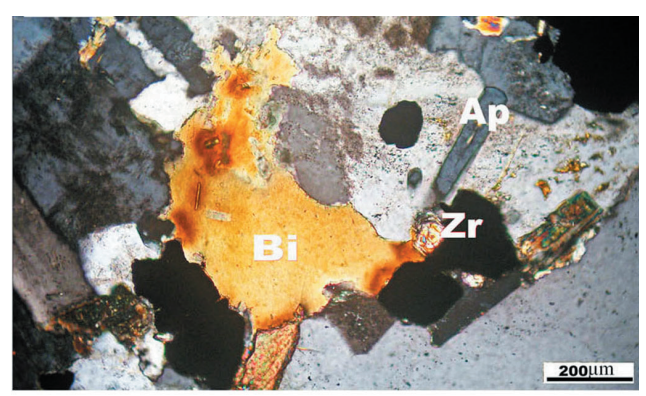

Fig.6: Accessory assemblage of biotite, zircon and apatite in the syenogranite, $x p l$. Bi: biotite, $\mathrm{Zr}$ : zircon, Ap: apatite

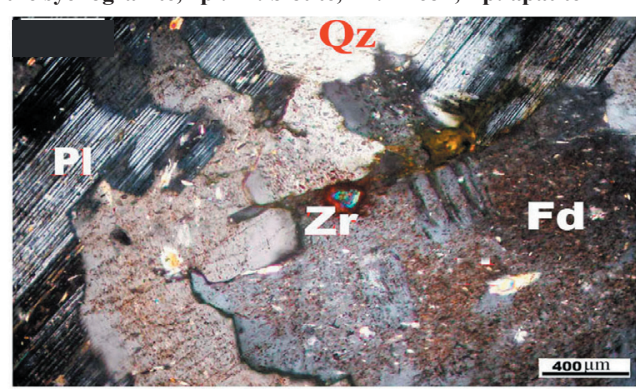

Fig.7: The main rock-forming minerals in the alkali feldspar granite, xpl Fd: k-feldspar, Pl: plagioclase, Zr: zircon

The field and mineralogical investigations indicate that the alkali feldspar granite is affected by more than one type of hydrothermal solutions nearly close to the formation of secondary uranium minerals. The hydrothermal solutions cause many mineralogical changes in the granite rock-forming minerals:

The K-feldspar crystals are somewhat cloudy by minute hematite inclusions. The potassic altered variety is the product of hydrothermal replacement of K-feldspar by sericite. Plagioclase is commonly bent and fractured reflecting strong deformation effects to which the rocks were subjected. The crystals are partially altered to sericite and stained with hematite.

Two types of quartz occur in variable proportion in the altered granite. The first is the magmatic quartz (Qz1) occurring as anhedral 
to subhedral crystals. The second is newly formed amorphous quartz (Qz2), occurring occasionally in the interstitial spaces between feldspars and/or surround the magamtic quartz (Qz1) (Fig. 8).

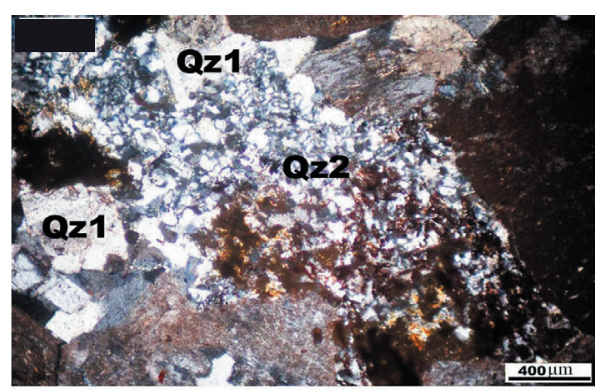

Fig.8: Secondary generation of amorphous quartz (Qz2) at the expense of magmatic quartz (Qz1) in the altered alkali feldspar granite, $\mathrm{xpl}$

Chloritization of biotite occurs together with silicification and carbonatization in many samples throughout the hydrothermally altered rocks and also in the least altered alkali feldspar granite.

The main stage of mineralizations is characterized by the deposition of vug-filling secondary uranium minerals. They appear to have precipitated within the pore spaces between feldspars or fill the cracks throughout the minerals. In some cases, they fill vugs formed by dissolution of the magmatic quartz (Fig.9). These secondary uranium minerals are always associated with large amounts of amorphous quartz.

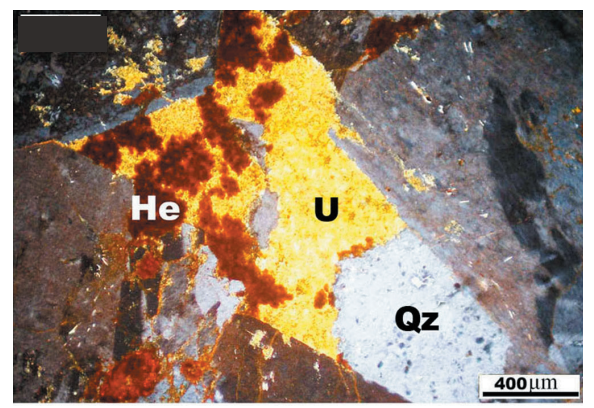

Fig.9: Secondary uranium minerals replacing the magmatic quartz in the altered alkali feldspar granite, xpl ;He: hematite, U: secondary uranium minerals
Zircon, monazite, apatite and fluorite representing the most important accessory minerals in the least altered granite were affected by hydrothermal alterations. The petrographic studies of the altered rocks indicated that zircon and monazite are partially affected by hydrothermal fluids along the crystal boundary (Fig.10) also apatite is partially affected too. Fluorite crystals are changed to blue-violet and purple colors due to the action of radiation.

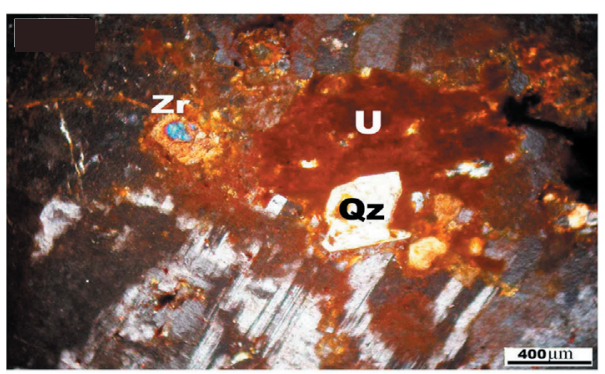

Fig. 10: Partial dissolution through the outer zone of zircon in the altered alkali feldspar granite, $\mathrm{xpl}$

In the altered granite, hydrothermal sulphide ore minerals as sphalerite, galena and minor pyrite are documented in the uranium occurrence $1 \mathrm{U}$. They occur as scattered disseminated grains in the host granite. Pyrite grains are mostly anhedral to subhedral while sphalerite and galena are mostly of anhedral form and filling intergranular spaces of $\mathrm{K}$ feldspar (Fig.11). Textural and mineralogical evidences indicate that the deposition of sulphides appears to be pre-uranium minerals deposition.

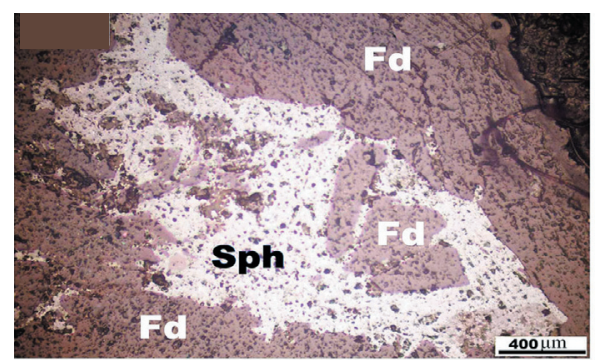

Fig.11: Sphalerite filling the intergranular spaces of K-feldspar in the altered alkali feldspar granite, ppl; Sph: sphalerite, Fd: k-feldspar 
Limited alteration of magnetite to hematite and limonite manifests superficial weathering and represents late oxidation stage in the altered rocks. Early stages of hematitization are recorded as a slight reddening of feldspar and through the alteration of biotite to chlorite. With progressive alterations, the degree of hematitization increases and clearly overprints all the pre-existing minerals.

The X-ray diffraction patterns for the secondary uranium minerals confirmed the presence of beta-uranophane and kasolite. Betauranophane $\left[\mathrm{Ca}\left(\mathrm{UO}_{2}\right)_{2} \mathrm{SiO}_{3}(\mathrm{OH}) 2 \cdot 5 \mathrm{H}_{2} \mathrm{O}\right]$ is recorded in most of the mineralized samples while kasolite $\left[\mathrm{Pb}\left(\mathrm{UO}_{2}\right)\left(\mathrm{SiO}_{4}\right) \cdot \mathrm{H}_{2} \mathrm{O}\right]$ is only identified in the uranium occurrence $1 \mathrm{U}$. These minerals are generally distinguished by their bright yellow color and characterized by their softness to be crushed by pressing with the picking needle.

Microscopically, the beta-uranophane grains are present as massive, radiated or tufted aggregates and dense microcrystalline masses. The crystals exhibit poorly developed faces that didn't afford good morphological measurements. The grains display pale yellow color (Fig.12a) and are occasionally stained with brownish hematite.

Kasolite is the only uranyl silicate with lead as major cation. It is generally distinguished from the other uranium silicates by its crystal habit and luster (Dawood et al., 2010). The studied grains occur in massive granular forms of yellowish-brown to reddish-orange colors (Fig.12b) composed of druses of rodlike crystals.

The BSE images display that the two minerals exist as a tabular crystals with radial fibrous aspect (Fig.13,14). The EDS analysis of beta-uranophane confirms its structural formula with $\mathrm{U}(65.43 \%), \mathrm{Si}(18.57)$ and $\mathrm{Ca}$ (7.33). On the other hand, the EDS analysis of kasolite shows uranium (40.34\%) and lead $(45.29 \%)$ as the principle elements with considerable amount of $\mathrm{Si}(6.17 \%)$ and $\mathrm{K}$ $(7.52 \%)$.
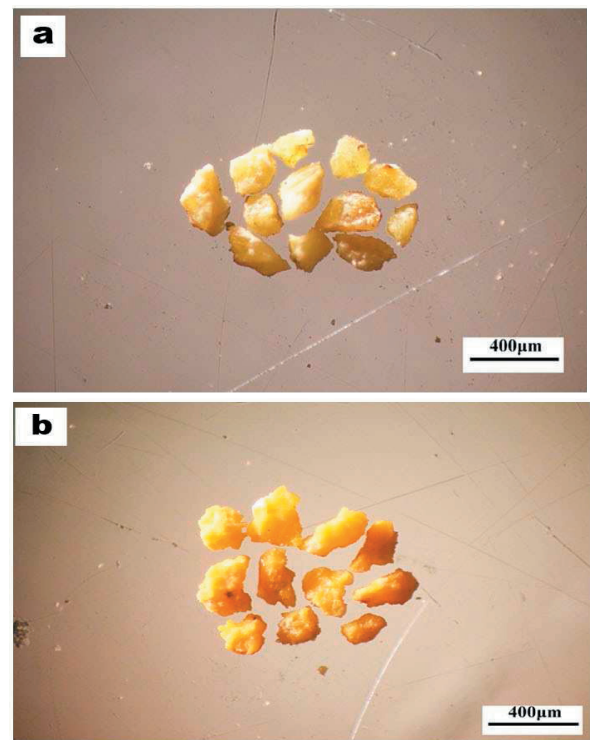

Fig.12: Photomicrographs of beta-uranophane (a) and kasolite (b) grains picked from the mineralized alkali feldspar granite

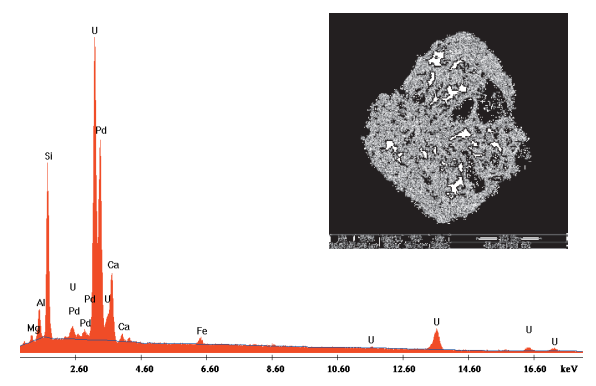

Fig.13: ESEM image and its EDX spectrum of betauranophane

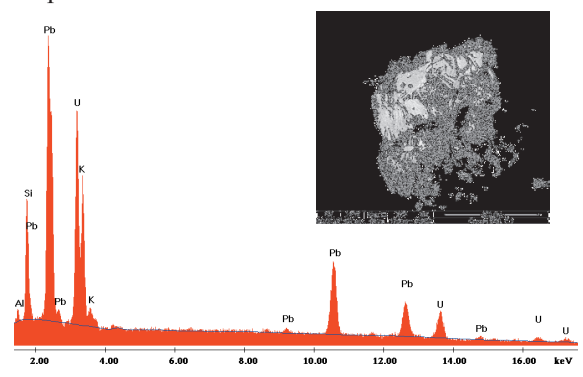

Fig.14: ESEM image and its EDX spectrum of kasolite 


\section{GEOCHEMISTRY}

\section{Gabal Abu Harba Granites}

The chemical analyses of sixteen representative samples from G. Abu Harba granites are shown in Tables (1\&2). They are syenogranite and alkali feldspar granite on the Ab-Or-An diagram (Fig.15; Streckeisen, 1976). Overall, the studied granites are high in silica and alkalis (Table 1). All analysed samples represent highly fractionated granites, with a differentiation index (D.I.) ranging from 88.31 to 98.69 (Table 1). According to the aluminum saturation index (ASI) of Zen (1986), the granites are mainly metaluminous to slightly peraluminous (Table 1). They all plot as calc-alkalic to alkali-calcic rocks on the $\mathrm{Na}_{2} \mathrm{O}+\mathrm{K}_{2} \mathrm{O}-\mathrm{CaO}$ vs. silica diagram (Fig.16) of Frost et al. (2001).
The syenogranite represents a separate group that is distinctive by lower concentration of $\mathrm{SiO}_{2}, \mathrm{Rb}, \mathrm{Nb}$ and higher contents of $\mathrm{CaO}, \mathrm{Sr}$, $\mathrm{Ba}, \mathrm{TiO}_{2}$ and $\mathrm{MgO}$ (Tables $1 \& 2$ ). The $\mathrm{Zr}$ contents decreases from the syenogranite toward the alkali feldspar granite. Primitive mantleand chondrite-normalized plots according to Sun and McDonough (1989) for the syenogranite and alkali feldspar granite show negative anomalies with $\mathrm{Ti}, \mathrm{P}, \mathrm{Sr}, \mathrm{Pb}$ and $\mathrm{Ba}$ (Fig.17). The depletion is not strong in the alkali feldspar granite, pointing to that the anomalies in this granite type intensifying fractional crystallization.

The two types of granite also differ in their REE patterns (Fig.18). The REE patterns display

Table 1 : Major and trace element concentrations with some parameters and ratios of the investigated granites

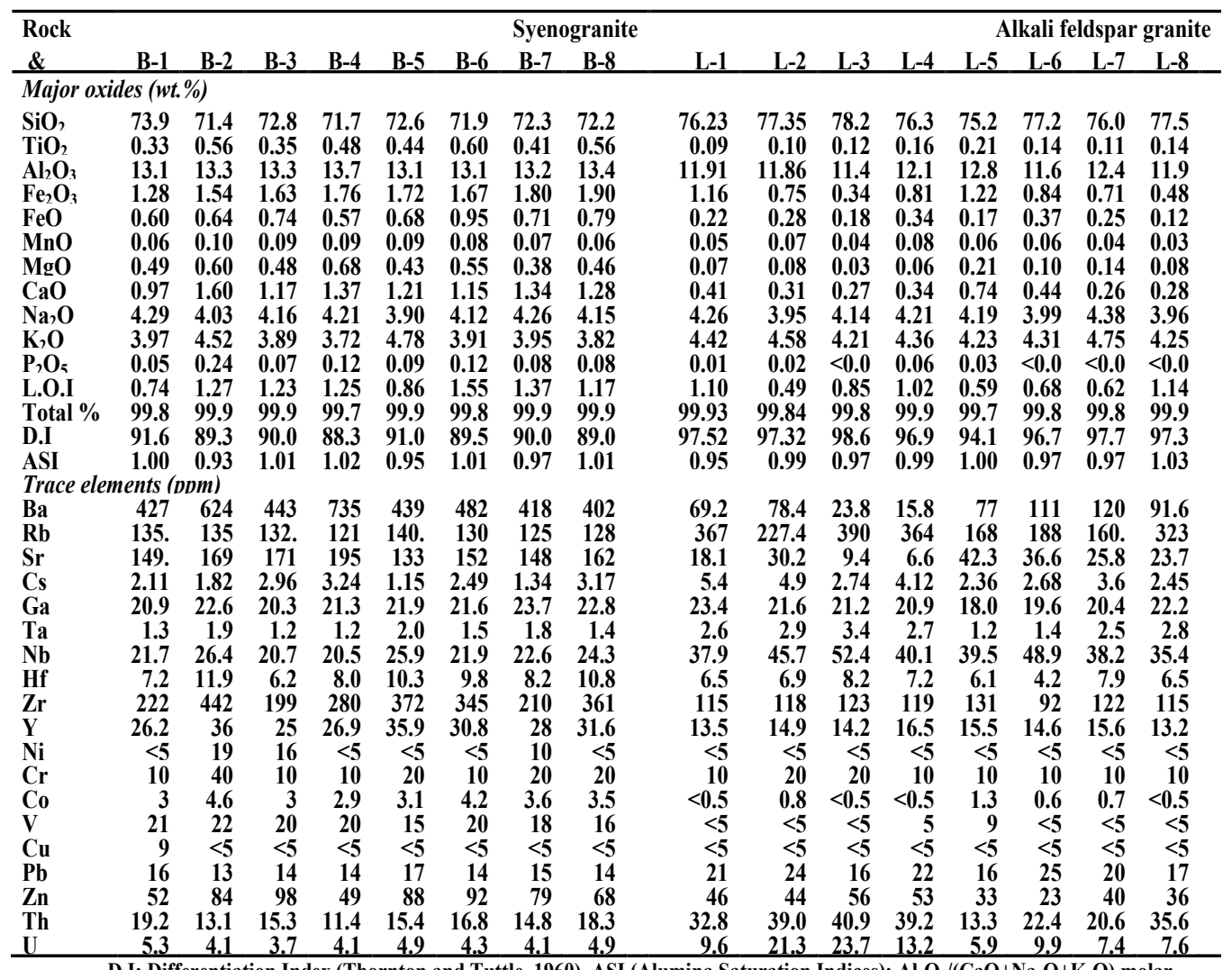

D.I: Differentiation Index (Thornton and Tuttle, 1960), ASI (Alumina Saturation Indices): $\mathrm{Al}_{2} \mathrm{O}_{3} /\left(\mathrm{CaO}+\mathrm{Na}_{2} \mathrm{O}+\mathrm{K}_{2} \mathrm{O}\right)$ molar 


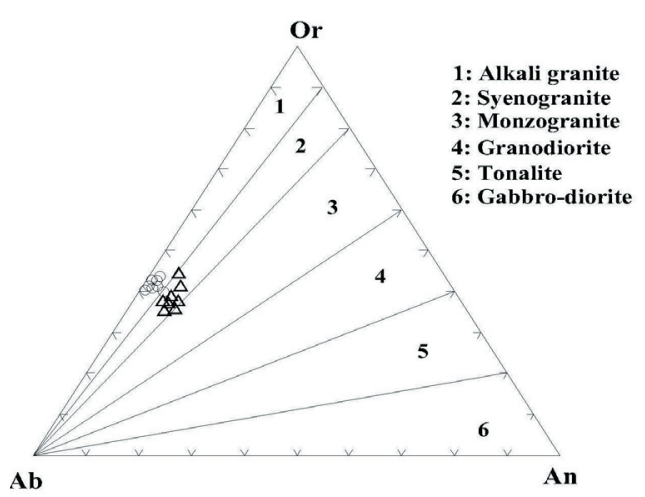

Fig.15: Normative An-Ab-Or ternary plot for the studied granites according to Streckeisen, $1976 ; \Delta$ : syenogranite, $\bigcirc$ : alkali feldspar granite

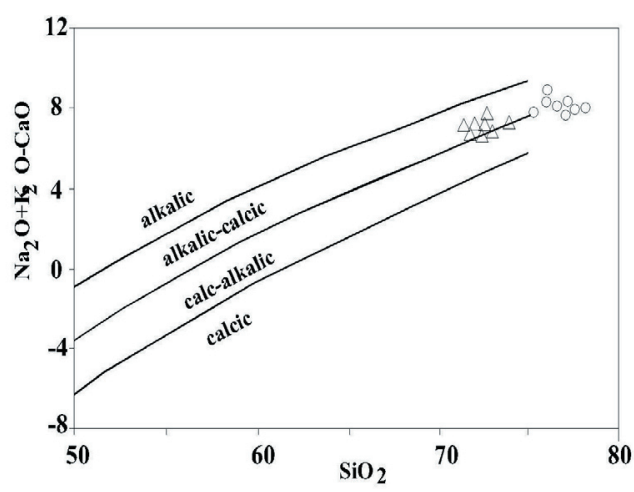

Fig.16: $\mathrm{SiO}_{2}$ vs $\mathrm{Na}_{2} \mathrm{O}+\mathrm{K}_{2} \mathrm{O}-\mathrm{CaO}$ discrimination diagram for the studied granites according to Frost et al. 2001; $\Delta$ : syenogranite, $\circ$ : alkali feldspar granite (a)

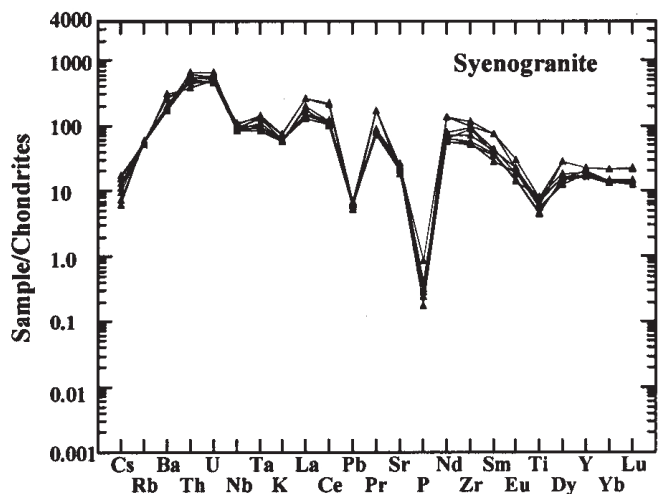

(b)

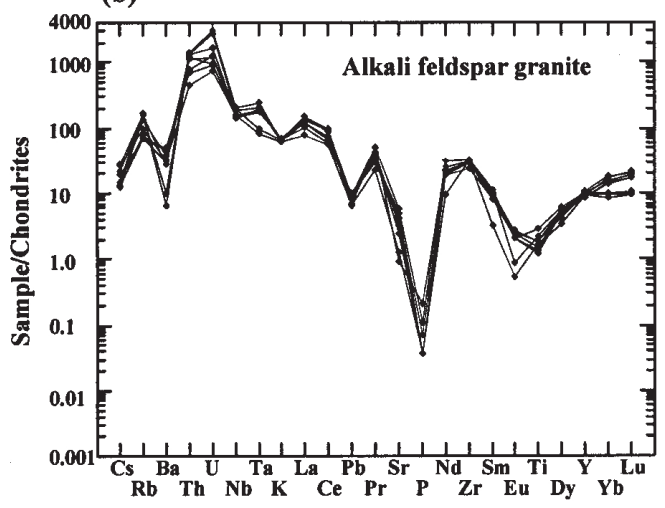

Fig.17: Primitive mantle normalized-multi element diagrams $(a, b)$; Normalizing values of primitive mantle and chondrite are according to Sun and McDonough (1989).

Table 2 : Rare earth elements analyses of the studied granites

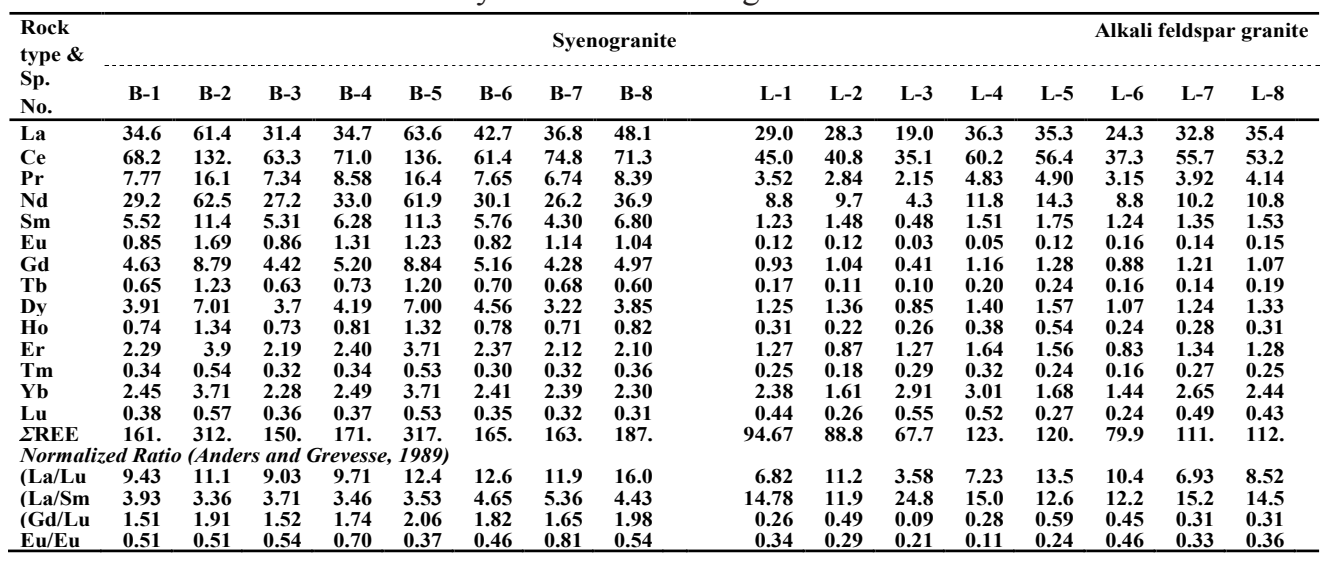


a gull-wing shape, characterized by highly to moderately fractionated patterns and high LREE relative to the MREE and HREE contents. The studied granites have a steadily decreasing $\mathrm{Eu} /$ $\mathrm{Eu}^{*}$ values from the syenogranite toward the alkali feldspar granite with simultaneous decrease in the $\Sigma$ REE contents (Table 2).

On the A/CNK-A/NK diagram of Maniar and Picoli (1989), the studied granites fall within the field of post-orogenic granite (Fig.19). On the normative composition of Qz-Ab-Or ternary plot of Johannes and Holtz (1996), the granites have minimum melt composition (730760OC) and different $\mathrm{P}_{\mathrm{H} 2 \mathrm{O}}$ (1-5kbar) ((Fig. 20). This may favor a low water pressure during the evolution of G. Abu Harba granites.

\section{The Altered Alkali Feldspar Granite}

This paper presents a series of geochemical analyses of the metasomatized rocks in Gabal Abu Harba alkali feldspar granite (Table 3). The mineralogical and chemical data suggest at le ast two main varieties of
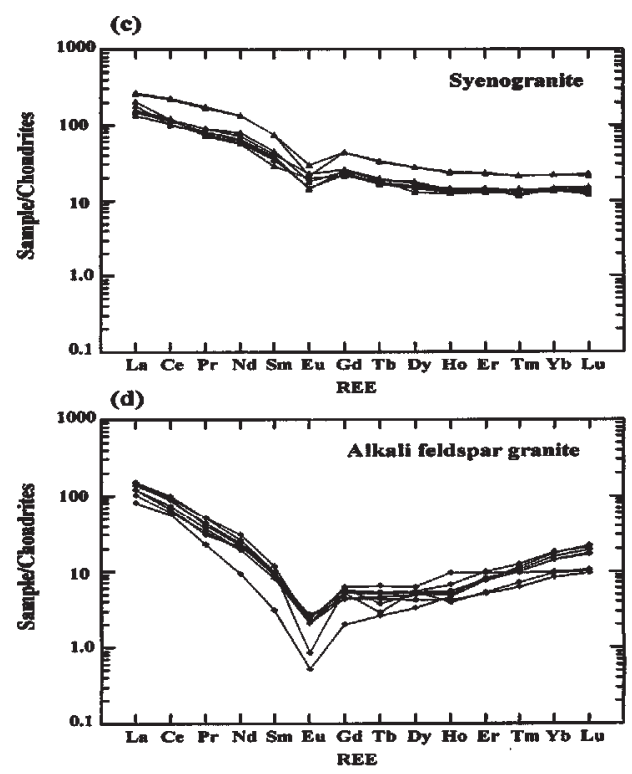

Fig.18:Chondrite-normalized REE patterns for the studied granites(a,b); Normalizing values of primitive mantle and chondrite are from Sun and McDonough (1989). post-magmatic hydrothermal alterations. They are sodic and potassic metasomatism, which can be discriminated well in the Q-P diagram of Debon and Le Fort (1983). This plot distinguishes four major groups; (1) albitization followed by desilicification, (2) albitization with simultaneous desilicification, (3) incipient desilicification and (4) potassic metasomatism (Fig.21). The altered rocks are dominated by moderately to highly sodic metasomatism eight samples. The potassic metasomatism is displayed by three samples follow this trend.

\section{Element Mobility}

In order to calculate the gain or loss of each element in the altered alkali feldspar granite, isocon diagrams for the sodic and potassic varieties are constructed, as proposed by Grant (1986). Each metasomatic stage is normalized to the unaffected alkali feldspar granite. Aluminum has been chosen as the less mobile element during mass balance calculations according to Grant (1986).

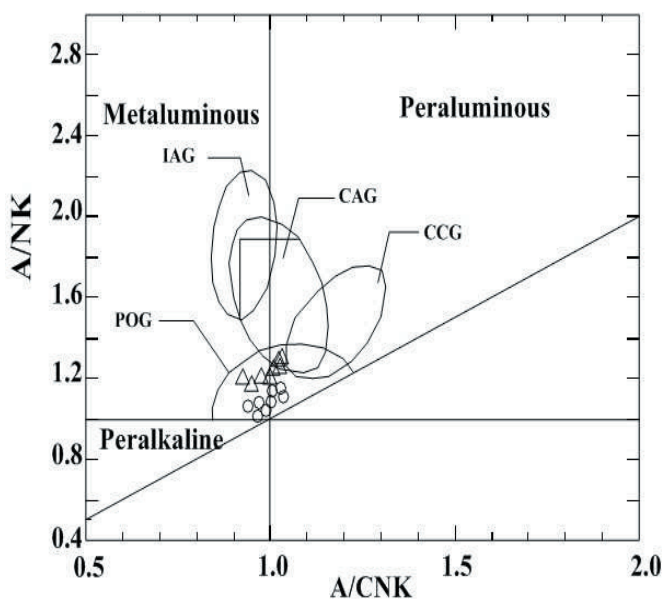

Fig.19: Tectonic discrimination diagrams of the studied granites as $\mathrm{A} / \mathrm{CNK}$ vs $\mathrm{A} / \mathrm{NK}$ molar ratios according to Maniar and Piccoli (1989); $\Delta$ : syenogranite, ○: alkali feldspar granite 


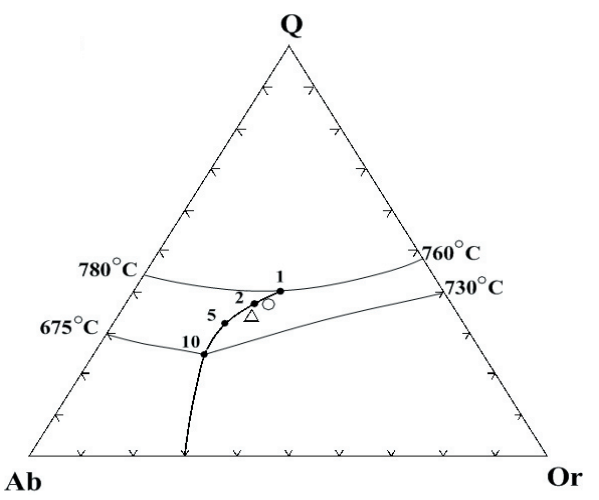

Fig.20: Tectonic discrimination diagrams of the studied granites as haplogranite system Qz-Ab-Or according to Johannes and Holtz (1996); $\Delta$ : syenogranite, o: alkali feldspar granite

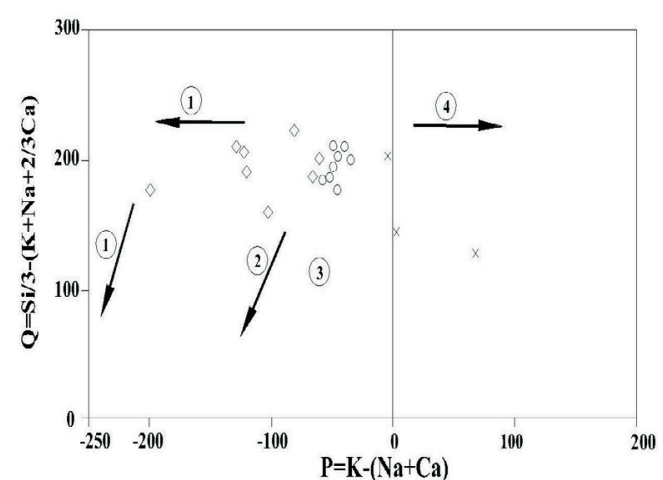

Fig.21: Q-P diagram of Debon and Le Fort (1983) illustrates the compositional characteristics of the altered alkali feldspar granite compared to the least altered equivalent. $\circ$ : least altered alkali feldspar granite, $\diamond$ : sodic metasomatism, $\times$ : potassic metasomatism.

Table 3 : Major and trace element concentrations with some parameters and ratios of the studied altered alkali feldspar granite

\begin{tabular}{|c|c|c|c|c|c|c|c|c|c|c|c|c|}
\hline \multirow{2}{*}{$\begin{array}{l}\text { Rock varieties } \\
\text { \& Sp. No. }\end{array}$} & \multirow{2}{*}{$\begin{array}{l}\text { Av. alkali } \\
\text { feldspar } \\
\text { granite } \\
\text { No.=8 }\end{array}$} & \multicolumn{2}{|c|}{ Na-metasomatism } & \multirow[b]{2}{*}{ M-3 } & \multirow[b]{2}{*}{ M-4 } & \multirow[b]{2}{*}{ M-5 } & \multirow[b]{2}{*}{ M-6 } & \multirow[b]{2}{*}{ M-7 } & \multicolumn{3}{|c|}{ K-metasomatism } & \multirow[b]{2}{*}{ M-1 } \\
\hline & & R-3 & R-4 & & & & & & M-8 & R-1 & R-2 & \\
\hline \multicolumn{13}{|c|}{ Major oxides (wt. \%) } \\
\hline $\mathrm{SiO}_{2}$ & 76.79 & 76.28 & 76.45 & 75.28 & 76.00 & 75.90 & 74.05 & 77.39 & 77.16 & 70.52 & 73.12 & 67.54 \\
\hline $\mathrm{TiO}_{2}$ & 0.13 & 0.07 & 0.06 & 0.09 & 0.07 & 0.10 & 0.11 & 0.10 & 0.11 & 0.09 & 0.06 & 0.10 \\
\hline $\mathbf{A l}_{2} \mathrm{O}_{3}$ & 12.05 & 13.15 & 12.79 & 12.50 & 12.85 & 12.48 & 12.72 & 11.94 & 11.82 & 16.89 & 14.45 & 17.28 \\
\hline $\mathrm{Fe}_{2} \mathrm{O}_{3}$ & 0.79 & 1.26 & 0.89 & 1.85 & 1.87 & 1.64 & 2.82 & 1.43 & 1.75 & 0.92 & 2.11 & 2.35 \\
\hline $\mathrm{FeO}$ & 0.24 & 0.25 & 0.16 & 0.18 & 0.20 & 0.22 & 0.11 & 0.16 & 0.14 & 0.28 & 0.12 & 0.13 \\
\hline MnO & 0.05 & 0.09 & 0.07 & 0.19 & 0.11 & 0.11 & 0.14 & 0.12 & 0.18 & 0.06 & 0.04 & 0.20 \\
\hline MgO & 0.10 & 0.09 & 0.10 & 0.07 & 0.11 & 0.07 & 0.08 & 0.07 & 0.08 & 0.12 & 0.09 & 0.08 \\
\hline $\mathrm{CaO}$ & 0.38 & 0.28 & 0.26 & 0.42 & 0.27 & 0.33 & 0.38 & 0.46 & 0.43 & 0.29 & 0.31 & 0.22 \\
\hline $\mathrm{Na}_{2} \mathrm{O}$ & 4.14 & 5.15 & 5.37 & 4.43 & 6.77 & 4.22 & 5.32 & 5.18 & 4.25 & 3.66 & 3.05 & 2.69 \\
\hline $\mathbf{K}_{2} \mathbf{O}$ & 4.39 & 2.23 & 2.74 & 3.96 & 1.13 & 3.85 & 3.56 & 2.32 & 3.05 & 5.90 & 4.76 & 7.53 \\
\hline $\mathbf{P}_{2} \mathrm{O}_{5}$ & 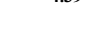 & $<0.01$ & $<0.01$ & $<0.01$ & $<0.01$ & $<0.01$ & $<0.01$ & 0.01 & $<0.01$ & $<0.01$ & $<0.01$ & 0.01 \\
\hline L.O.I & & 0.94 & 0.84 & 0.90 & 0.50 & 1.09 & 0.52 & 0.62 & 0.80 & 1.25 & 1.66 & 1.80 \\
\hline Total & & 99.8 & 99.74 & 99.88 & 99.89 & 100.02 & 99.82 & 99.8 & 99.78 & 99.99 & 99.78 & 99.93 \\
\hline \multicolumn{13}{|c|}{ Trace Elements (ppm) } \\
\hline Ba & 73.4 & 128.6 & 110.4 & 100.0 & 58.6 & 33.2 & 26.4 & 27.8 & 24.3 & 96.7 & 116.5 & 222.0 \\
\hline $\mathbf{R b}$ & 273.4 & 382 & 387 & 395 & 8.9 & 481 & 354 & 82.8 & 396 & 418 & 368 & 435 \\
\hline $\mathrm{Sr}$ & 24.1 & 102.7 & $\mathbf{9 8 . 2}$ & 90.8 & 90.2 & 90.1 & 114.2 & 85.9 & 69.8 & 10.6 & 18.3 & 32.5 \\
\hline Cs & 3.53 & 3.76 & 3.31 & 3.04 & 2.78 & 4.23 & 3.65 & 3.97 & 4.88 & 1.12 & 2.01 & 3.31 \\
\hline Ga & 20.9 & 20.3 & 17.9 & 26.8 & 19.3 & 25.6 & 21.8 & 19.9 & 23.2 & 28.9 & 21.8 & 30.0 \\
\hline Ta & 2.4 & 3.6 & 4.2 & 4.8 & 4.1 & 4.4 & 4.1 & 4.3 & 3.8 & 3.9 & 3.3 & 3.7 \\
\hline $\mathbf{N b}$ & 42.3 & 51.8 & 55.4 & 54.9 & 48.8 & 63.8 & 60.9 & 66.2 & 54.0 & 52.6 & 39.2 & 62.6 \\
\hline Hf & 6.69 & 7.17 & 6.53 & 6.84 & 7.09 & 6.69 & 6.21 & 7.66 & 7.62 & 9.13 & 8.35 & 7.86 \\
\hline $\mathbf{Z r}$ & 117 & 113 & 116 & 111 & 129 & 108 & 135 & 139 & 129 & 140 & 143 & 165 \\
\hline $\mathbf{Y}$ & 14.8 & 15.7 & 15.4 & 16.1 & 13.6 & 17.6 & 16.9 & 17.4 & 15.2 & 14.8 & 14.1 & 15.3 \\
\hline $\mathrm{Ni}$ & & $<5$ & $<5$ & $<5$ & 7 & $<5$ & $<5$ & 6 & $<5$ & $<5$ & $<5$ & $<5$ \\
\hline $\mathrm{Cr}$ & 12.5 & $<10$ & $<10$ & $<10$ & $<10$ & $<10$ & $<10$ & $<10$ & $<10$ & $<10$ & $<10$ & $<10$ \\
\hline Co & 12.0 & $<0.5$ & 5 & $<0.5$ & 1.3 & $<0.5$ & 0.6 & 0.8 & $<0.5$ & 5 & 0.7 & $<0.5$ \\
\hline $\mathrm{v}$ & & $<5$ & $<5$ & $<5$ & $<5$ & $<5$ & $<5$ & $<5$ & $<5$ & 7 & $<5$ & 14 \\
\hline $\mathrm{Cu}$ & & 6 & 6 & 21 & 25 & 18 & 12 & 12 & 20 & $<5$ & $<5$ & 86 \\
\hline Pb & 20.0 & 28 & 22 & 82 & 63 & 40 & 50.7 & 48 & 26 & 18 & 16 & 2920 \\
\hline $\mathbf{Z n}$ & 41.4 & 118 & 340 & 790 & 65 & 288 & 256 & 88 & 104 & 128 & 90 & 5690 \\
\hline Th & 30.45 & 43.5 & 43.4 & 51.6 & 47.8 & 49.3 & 48.3 & 52.9 & 52.7 & 41.9 & 48.8 & 50.4 \\
\hline $\mathbf{U}$ & 12.31 & 52.5 & 123 & 350 & 311 & 401 & 388 & 439 & 406 & 8.60 & 7.75 & 241 \\
\hline \multicolumn{13}{|l|}{ REE (ppm) } \\
\hline La & 30.0 & 15.3 & 18.9 & 32.5 & 21.4 & 27.1 & 30.1 & 44.6 & 41.1 & 15.6 & 10.8 & 37.6 \\
\hline $\mathrm{Ce}$ & 47.96 & 38.2 & 39.2 & 63.6 & 40.8 & 47.8 & 51.3 & 72.8 & 69.1 & 36.2 & 32.4 & 60.5 \\
\hline Pr & 3.68 & 2.30 & 2.97 & 3.89 & 3.01 & 3.74 & 4.05 & 5.94 & 5.40 & 2.18 & 1.29 & 4.05 \\
\hline Nd & 9.80 & 6.3 & 5.3 & 8.9 & 7.9 & 8.5 & 9.0 & 13.2 & 12.2 & 4.4 & 3.1 & 8.4 \\
\hline Sm & 1.32 & 0.84 & 1.03 & 1.25 & 1.12 & 1.07 & 1.02 & 1.52 & 1.45 & 0.68 & 0.56 & 1.05 \\
\hline Eu & 0.11 & 0.05 & 0.05 & 0.08 & 0.13 & 0.07 & 0.03 & 0.03 & 0.05 & 0.07 & 0.08 & 0.09 \\
\hline Gd & 1.00 & 0.56 & 0.67 & 0.70 & 0.74 & 0.68 & 0.65 & 0.86 & 0.84 & 0.45 & 0.44 & 0.58 \\
\hline $\mathbf{T b}$ & 0.16 & 0.12 & 0.13 & 0.17 & 0.13 & 0.16 & 0.15 & 0.21 & 0.19 & 0.11 & 0.11 & 0.14 \\
\hline Dy & 1.26 & 0.98 & 0.85 & 1.33 & 0.87 & 1.24 & 1.16 & 1.56 & 1.42 & 0.85 & 0.94 & 1.04 \\
\hline Ho & 0.32 & 0.21 & 0.24 & 0.30 & 0.23 & 0.35 & 0.34 & 0.39 & 0.37 & 0.22 & 0.28 & 0.28 \\
\hline Er & 1.26 & 0.97 & 0.96 & 1.35 & 0.99 & 1.61 & 1.55 & 1.79 & 1.6 & 0.95 & 1.28 & 1.31 \\
\hline Tm & 0.25 & 0.24 & 0.26 & 0.29 & 0.21 & 0.34 & 0.33 & 0.33 & 0.31 & 0.22 & 0.28 & 0.27 \\
\hline $\mathbf{Y b}$ & 2.27 & 2.59 & 2.29 & 3.01 & 2.08 & 3.31 & 3.35 & 3.14 & 3.09 & 2.12 & 2.81 & 2.82 \\
\hline Lu & 0.40 & 0.42 & 0.46 & 0.58 & 0.39 & 0.61 & 0.60 & 0.58 & 0.54 & 0.38 & 0.54 & 0.55 \\
\hline ¿REE & 99.86 & 69.13 & 73.20 & 117.95 & 80.00 & 96.56 & 103.63 & 146.90 & 137.66 & 64.41 & 54.91 & 118.68 \\
\hline Normalized Ratio & (Anders ar & Ind Greves. & $1989)$ & & & & & & & & & \\
\hline$(\mathbf{L a} / \mathbf{L u})_{\mathrm{N}}$ & 8.54 & 3.77 & 4.25 & 5.80 & 5.68 & 4.60 & 5.19 & 7.95 & 7.88 & 4.25 & 2.07 & 7.08 \\
\hline$(\mathrm{La} / \mathrm{Sm})_{\mathrm{N}}$ & 15.16 & 11.42 & 11.50 & 16.29 & 11.98 & 15.88 & 18.51 & 18.38 & 17.76 & 14.39 & 12.08 & 22.44 \\
\hline$(\mathbf{G d} / \mathbf{L u})_{\mathrm{N}}$ & 0.35 & 0.16 & 0.18 & 0.15 & 0.23 & 0.14 & 0.13 & 0.18 & 0.19 & 0.15 & 0.10 & 0.13 \\
\hline $\mathbf{E u} / \mathbf{E} \mathbf{u}^{*}$ & 0.29 & 0.22 & 0.18 & 0.26 & 0.43 & 0.25 & 0.11 & 0.08 & 0.14 & 0.38 & 0.49 & 0.35 \\
\hline
\end{tabular}


$\left(\Delta \mathrm{C}_{\mathrm{i}} / \mathrm{C}_{\mathrm{i}}^{\mathrm{o}}\right)=\left(\mathrm{C}_{\mathrm{Al}_{2} \mathrm{O}_{3}}^{\mathrm{o}} / \mathrm{C}_{\mathrm{Al}_{2} \mathrm{O}_{3}}^{\mathrm{A}}\right)\left(\mathrm{C}_{\mathrm{i}}^{\mathrm{A}} / \mathrm{C}_{\mathrm{i}}^{\mathrm{o}}\right)-1$

Where; O: Superscript for least altered samples,A: Superscript for altered samples, i: Subscript for component,C: Concentration, $\Delta \mathrm{C}$ : Change in concentration.

In the two altered varieties, $\mathrm{Al}, \mathrm{Ga}, \mathrm{Zr}$ and Hf show a coherent behavior. These trace elements are considered to be almost immobile in the present case. A volume loss during metasomatic alteration caused relative enrichment of these elements but did not significantly affect the ratio values between these elements. For this reason these elements appeared to be the most suitable for defining the isocon according to Grant (1986).

The isocon flotifor the 2 odicariety shows little close correlation with that of the least altered alkali feldspar granite and has a correction factor of (Fig.22a).

The potassic isocon, on the other hand, has a calculated correction factor of 0.77 , which is more deviated than the sodic one, reflecting intense alteration and large volume loss (Fig.22b). The relative concentration changes for major-, trace- and REE in the sodic and potassic varieties relative to the least altered precursor are presented graphically on Figs. (23\&24).

Marked depletion in $\mathrm{SiO}_{2}$ contents of the altered rocks is directly related to desilicification process affected the magmatic quartz. Magnesium, manganese and iron are liberated by the alteration of biotite to chlorite (Ewers et al., 1983). Calcium generally decreases with respect to original alkali feldspar granite, which itself has low initial $\mathrm{Ca}$ values (Figs.23\&24).

The enrichment of $\mathrm{Na}_{2} \mathrm{O}$ in the sodic subset is exclusively due to the pseudomorphous albitization of plagioclase and the precipitation of authigenic albite, whereas the decrease in $\mathrm{K}_{2} \mathrm{O}$ is enhanced by chloritization of biotite. An expected $\mathrm{K}_{2} \mathrm{O}$ enrichment at the expense of $\mathrm{Na}_{2} \mathrm{O}$ in the potassic altered granite demonstrates the most significant trends with respect to sericitization. The distribution of
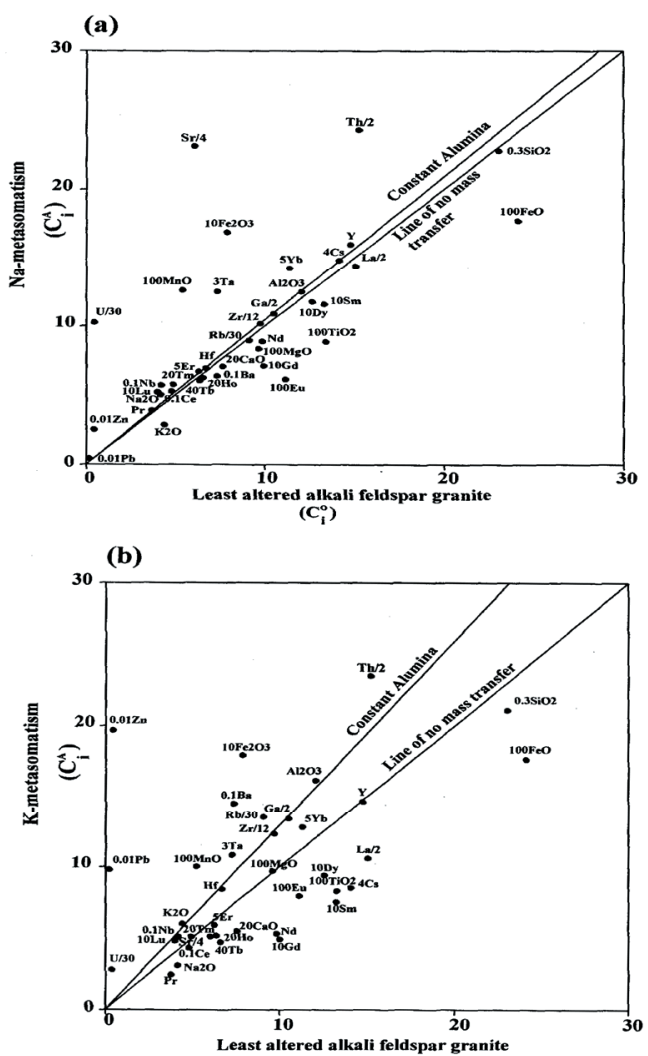

Fig.22: An isocon diagram for the studied sodic (a) and potassic (b) altered rocks relative to the least altered alkali feldspar granite as proposed by Grant (1986). Oxides are plotted in (Wt.\%) and trace elements are plotted in (ppm). The data for all components are scaled as shown

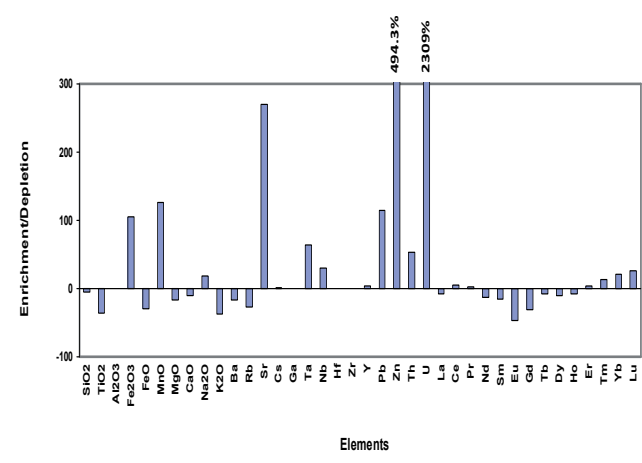

Fig.23: Relative mobility of major-, trace- and REE for the sodic altered rocks with respect to the least altered alkali feldspar granite. 


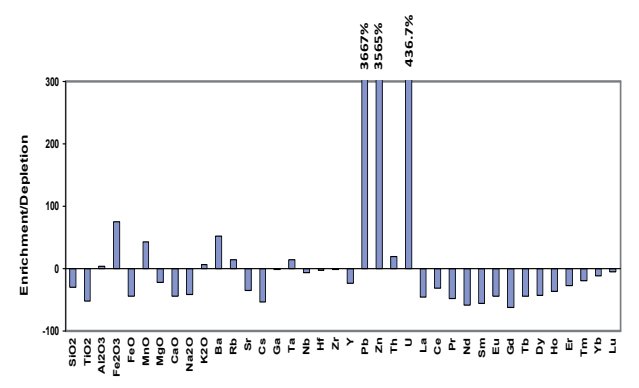

Elements
Fig.24: Relative mobility of major-, trace- and REE for potassic altered rocks with respect to the least altered alkali feldspar granite.

iron demonstrates a strong enrichment of $\mathrm{Fe}_{2} \mathrm{O}_{3}$ in the total altered subsets. Iron, mainly derived from the breakdown of biotite and chlorite, was oxidized into ferric iron and then precipitated as hematite. The oxidation of $\mathrm{Fe}$ is evidenced by the decrease in $\mathrm{FeO}$ and an accompanying increase in $\mathrm{Fe}_{2} \mathrm{O}_{3}$ contents (Figs.23\&24).

The potassic trend shows marked enrichment in $\mathrm{Zn}$ and $\mathrm{Pb}$, mineralogically confirmed by the formation of hydrothermal sulfide minerals in the mineralized sample No. M-1. This sample is selected from the uranium occurrence $1 \mathrm{U}$.

According to the isocon diagrams, the REE contents suggest significant mobility during hydrothermal alteration. Similar to the HFSE, the REE are usually considered to be immobile during hydrothermal alteration by aqueous fluids. Nevertheless, REE mobility in the crust is largely controlled by the nature of their host minerals and composition of fluids involved in water-rock interaction (Humphries, 1984). The mass balance calculations show a marked depletion-enrichment trend from $\mathrm{La}$ through Eu to Lu except for Ce and Pr which show slight enrichment, especially in the sodic altered granite.

\section{Distribution of $U$ and $T h$}

The U contents range from 3.7 to $5.3 \mathrm{ppm}$ in the syenogranite (Table 1), matching with the average upper crust value $(2.7 \mathrm{ppm}$, Rudnick and Gao, 2003). The alkali feldspar granite has $\mathrm{U}$ contents range from 5.9 to $23.7 \mathrm{ppm}$ (Table $1)$. The high abundances of $U$ in the samples No. L-2, L-3 and L-4, cause an increase for the average $U$ value of the alkali feldspar granite. The average $U$ contents (12.3ppm) classify this rock as anomalous granite, which is higher than that in typical granite $(3.2 \mathrm{ppm}$, Flanagan, 1976).

In the altered alkali feldspar granite, the formation of secondary uranium minerals is manifested by the increase in $U$ concentrations for most of the analysed samples. The uranium contents are ranging from 52.5 to 439 in the sodic metasomatism and are reached to $241 \mathrm{ppm}$ in the sample No. M-1 of the potassic metasomatism (Table 3). Uranium enrichment is associated with slight increase in Th contents among all the analysed samples (Table 3).

\section{CONCLUSION}

The late Pan-African granites of G. Abu Harba area are syenogranite and alkali feldspar granite. The geochemical classification, the major and trace element compositions indicate high-K metaluminous to slightly peraluminous granites. They originated from calc-alkaline to alkaline magma in post-orogenic environment. The more differentiated suite of G. Abu Harba granites (alkali feldspar granite) has uranium contents above the twice Clark abundance and constitutes a good environment for uranium minerals formation by later hydrothermal fluids.

Along well-definite structures, the alkali feldspar granite has subjected to more than one type of hydrothermal solutions causing many changes in its essential rock-forming minerals. The alkali metasomatism represents the major one and dominantly associates different styles of alterations such as chloritization, sericitization, kaolinitization, carbonatization and hematitization.

Sodic and potassic metasomatism are discriminated chemically in the altered rocks, which accompanied mobility and redistribu- 
tion for the most elements, notably $\mathrm{U}$, Th and REE. Zr, Hf, Ga and $\mathrm{Al}$ are inferred on textural grounds to be immobile. The most important element concentration changes in the altered rocks relative to the least altered alkali feldspar granite are the depletion of most of the major elements ( $\mathrm{Si}, \mathrm{Ti}, \mathrm{Mg}, \mathrm{Ca}$ and $\mathrm{K}$ ) and LREE with an enrichment of both the HREE ( Tm, $\mathrm{Yb}$ and $\mathrm{Lu}$ ) and most of the trace elements (U, Th, $\mathrm{Zn}$ and $\mathrm{Pb}$ ).

\section{REFERENCES}

Bentor, Y.K., 1985. The crustal evolution of the Arabo-NubianMassif with special reference to the Sinai Peninsula. Precambrian Research, 28, $1-74$.

Cuney, M., 2003. Uranium potential of Eastern Desert granite, Egypt. Unpublished Internal Report, Nuclear Materials Authority, Cairo, Egypt.

Cuney, M., 2009. The extreme diversity of uranium deposits. Miner Deposita. 44, 3-9.

Cuney, M.; Emetz, A.; Mercadier, J.; Mykchaylov, V.; Shunko, V., and Anatoliy Yuslenko, A., 2012. Uranium deposits associated with $\mathrm{Na}-$ metasomatism from central Ukraine. A review of some of the major deposits and genetic constraints. Ore Geology Reviews ,44, 82-106.

Dahlkamp, F.J., 1993. Uranium Ore Deposits. Springer-Verlag, Berlin, 460p.

Dawood, Y. H., Harbi, H. M., and Abd El-Naby, H. H., 2010.Genesis of kasolite associated with aplite-pegmatite at Jabal Sayid, Hijaz region, Kingdom of Saudi Arabia. J. Asian Earth Sci., 37, 1-9.

Debon, F., and Le Fort, P., 1983, A cationic classification of common plutonic rocks and their magmatic associations: principles, method, applications. Earth Sci., 73, 135-149.

Dill, H. G., Gerdes, A.; Weber, B., 2010. Age and mineralogy of supergene uranium mineralsTools to unravel geomorphological and palaeohydrological processes in granitic terrains
(Bohemian Massif, SE Germany). Geomorph., $117,44-65$.

Ewers, G. R., Ferguson, J., and Donnelly, T. H., 1983.The Nabarlek uranium deposit, northern territory, Australia: some petrologic and geochemical constraints on genesis. Econ. Geol., 78, 823-837.

Flanagan, F. J., 1976. 1972 compilation of data on USGS standards. In: Descriptions and analyses of eight new USGS rock standards (Flanagan, F.J., ed.). USGS professional paper 840,131183.

Frost, B. R.; Barnes, C. G.; Collins, W. J.; Arculus, R. J.; Ellis, D. J., and Frost, C. D., 2001. A Geochemical Classification for Granitic Rocks. J. Petrol., 42, 2033-2048.

Genna, A.; Nehlig, P.; Le Goff, E.; Guerrot, C., and Shanti, M., 2002. Proterozoic tectonism of the Arabian Shield. Pre. Res., 117, 21-40.

Grant, J. A., 1986. The isocon diagram- a simple solution to Gresens' equation for metasomatic alteration. Econ. Geol., 81, 1976-1982.

Humphries, S. E., 1984.The mobility of the rare earth elements in the crust. In: Rare earth geochemistry ( Henderson, P., ed.). Elsevier, Amsterdam, 315-341.

Johannes, W., and Holtz, F., 1996. Petrogenesis and Experimental Petrology of Granitic Rocks. Springer-Verlag, Berlin, 335p.

Kröner, A.; Greiling, R., Reischmann, T.; Hussein, I.M.; Stern, R.J.; Durr, S.; Krugger, J., and Zimmer, M., 1987. Pan-African crustal evolution in the Nubian segment of north-eastern Africa. In: Kröner, A. (ed.) Proterozoic Lithospheric Evolution. Am. Geophys. Union Geodynanic Series $15,235-257$.

Maniar, P. D., and Piccoli, P. M., 1989. Tectonic discrimination of granitoids. Geol. Soc. Amer. Bull., 101, 635-643. 
Meert, J.G., 2003. A synopsis of events related to the assembly of eastern Gondwana. Tectonophysics ,362,1-40.

Moussa, E. M.M.; Stern, R. J.; Manton, W. J., and Ali, K. A., 2008. SHRIMP zircon dating and $\mathrm{Sm} / \mathrm{Nd}$ isotopic investigations of Neoproterozoic granitoids, Eastern Desert, Egypt. Pre. Res., 160, 341-356.

Nex, P. A.; Kinnaird, J. A., and Oliver, G. J., 2001. Petrology, geochemistry and uranium mineralisation of post-collisional magmatism around Goanikontes, southern Central Zone, Damaran Orogen, Namibia. J. Afri. Earth Sci., 33, 481502.

Roz, M. E., 2001. Geology and uranium potentialities in Gabal Abu Harba environs, North Eastern Desert, Egypt. Ph.D. Thesis, Fac. Sci., Cairo Univ., 264p.

Rudnick, R.L., and Gao, S., 2003. Composition of the continental crust. Treatise on Geochem., 3, $1-64$.

Scaillet, S.; Cuney, M.; Le Carlier De Veslud, C.; Cheilletz, A., and Royer, J. J., 1996. Cooling pattern and mineralization history of the Saint Sylvestre and western Marche leucogranite pluton, French Massif Central: II. Thermal modeling and implications for the mechanisms of uranium mineralization. Geoch. Cosmo. Acta, $60,4673-4688$.
Stern, R.J., 1994. Arc assembly and continental collision in the Neoproterozoic East African Orogen: implications for the consolidation of Gondwanaland. Ann. Review of Earth Planet. Sci. 22, 319-351.

Stern, R.J.; Gottfried, D., and Hedge, C.E., 1984. Late Precambrian rifting and crustal evolution in the Northeastern Desert of Egypt. Geol., 12, $168-172$

Streckeisen, A., 1976b. To each plutonic rock its proper name. Earth Sci. Reviews, 12, 1-33.

Sun, S.S., and McDonough, W.F., 1989. Chemical and isotopic systematic of oceanic basalts; implications for mantle composition and processes. In: A.D. Saunders; M.J. Norry (eds.) Magmatism in the Ocean Basins. J.Geol. Soc., Special Publication 42, 313-345.

Zen, E.-An.,1986.Aluminum enrichment in silicate melts by fractional crystallization: some mineralogic and petrographic constraints. J. Petrol., 27, 1095-1117.

Zhao, K.; Jiang, S.; Dong, C.; Chen, W.; Chen, P.; Ling, H.; Zhang, J.; Kai-Xing Wang, K., 2011. Uranium-bearing and barren granites from the Taoshan Complex, Jiangxi Province, South China; Geochemical and petrogenetic discrimination and exploration significance. J. Geochem. Explor., 110, 126-135. 
الاحلال القلوى واعادة توزيع اليورانيوم والثوريوم والعناصر الارضية النادرة فى الاجزاء المتغيرة من جرانيت جبل

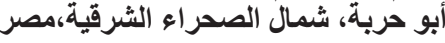

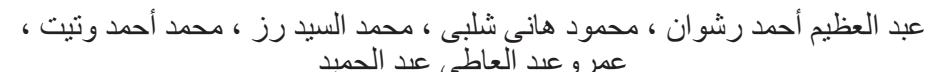

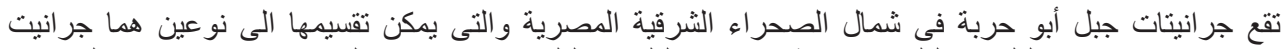

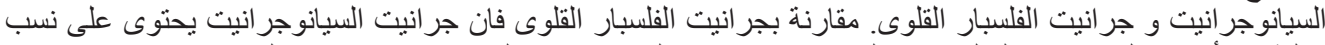

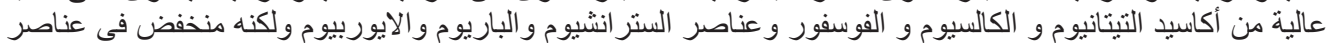

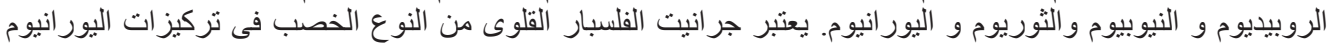

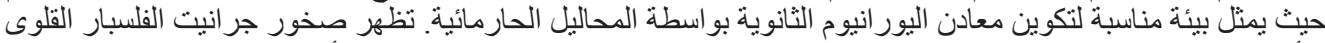

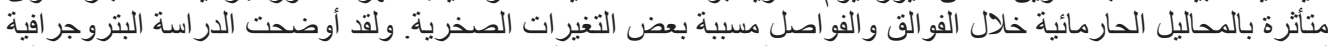

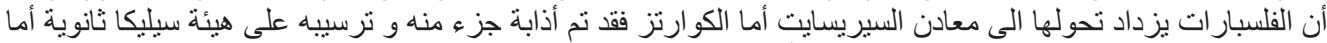

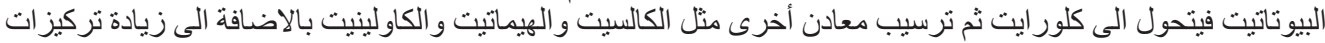

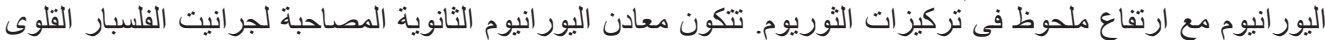

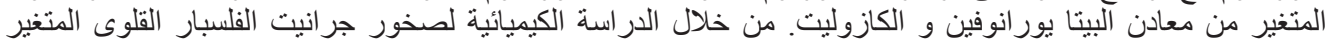

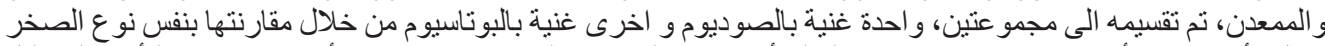

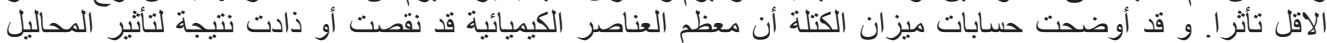

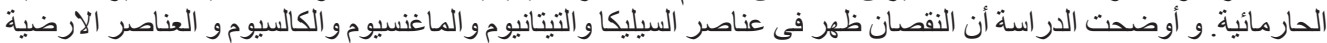
النادرة الخفيفة أما الزيادة فكانت فى معظم العناصر الثحيحة والعناصر النيكر الارضية النادرة الثقيلة. 